\title{
CAROLINGIAN KINGSHIP AND THE PEASANTS OF LE MANS : THE CAPITULUM IN CENOMANNICO PAGO DATUM ${ }^{1}$
}

In the late spring of 800 - or so the story goes - Charlemagne was passing through the area of Le Mans in western Francia. While there, he was asked to resolve the question of how much labour should be required from men described as fiscalini and homines ecclesiastici, dependants of royal estates and of the church respectively. Charlemagne acknowledged that there did not seem to be much of a logic to the current state of affairs, with great variation in what was being demanded. So, after consulting with his faithful followers, Charlemagne decreed that the labour service should depend on the assets of those who owed it. Those with enough oxen to equip a plough were to plough for their lord for one day a week. Those who owned fewer oxen would have to make up for it by performing manual labour. No one, though, could be requested to work for more than three days a week for their lord.

Charlemagne then made sure to have this decision formally written up and officially promulgated.

This text, the Capitulum in pago cenomannico datum, or Capitulary of Le Mans, may not be familiar to all readers by name, but it is very frequently to be encountered in footnotes ${ }^{2}$. Historians since Alfons Dopsch and even Montesquieu have invoked it to illuminate different aspects of Charlemagne's rule in a range of areas, including the nature of peasant labour and the appropriation of surplus ${ }^{3}$, peasant resistance to that appropriation ${ }^{4}$, royal practices of

\footnotetext{
${ }^{1}$ I am grateful to the audience at the conference held at the Deutsches Historisches Institut in Paris, as well as to audiences at the universities of St-Andrews and Leeds, for discussion of the paper on which this chapter is based, and to Jinty Nelson, Emma Hunter and Thomas Faulkner for their comments on a written version. I should also like to thank the organisers of the conference held in Paris in 2014 for their kind invitation.

${ }^{2}$ The standard edition is MGH. Capit., vol. I, ed. A. Boretius, Hanover, 1873, no. 31, p. 81-82. Earlier edition in MGH. Leges, vol. I, ed. G. Pertz, Hanover, 1835, p. 82. Both these editions were based on Paris, BnF, ms. lat. 5577. The earliest edition I am aware of is Karoli magni et Ludovici Pii, Christianiss. Regum et Impp. Francorum capitula sive leges ecclesiasticae et civiles, Paris, 1588, an edition of Benedict Levita alongside Ansegis. The capitulary is treated in some detail by A. Krah, «Zur Kapitulariengesetzgebung in und für Neustrien », in H. Atsma (ed.), La Neustrie. Les pays au nord de la Loire de 650 à 850, vol. II, Sigmaringen, 1989 (Beihefte der Francia, 16), p. 565-581.

${ }^{3}$ L. Kuchenbuch, Bäuerliche Gesellschaft und Klosterherrschaft im 9. Jahrhundert. Studien zur Sozialstruktur der Familia der Abtei Prüm, Stuttgart, 1978, p. 180 ; cf. id., «Bene laborare. Zur Sinnordnung der Arbeit, ausgehend vom capitulare de villis », in L. Bea and H. Reimöller (ed.), Von Aufbruch und Utopie. Perspektiven einer neuen Gesellschaftsgeschichte des Mittelalters. Für und mit Ferdinand Seibt aus Anlaß seines 65. Geburtstages, Cologne, 1992, p. 337-352.

${ }^{4}$ R. Hilton, Bond Men Made Free : Medieval Peasant Movements and the English Rising of 1381, London, 1973, p. 65 ; S. Epperlein, Herrschaft und Volk im karolingischen Imperium : Studien über soziale Konflikte und dogmatisch-politische Kontroversen im fränkischen Reich, Berlin, 1969, p. 26 ; E. Müller-Mertens, Karl der
} 
justice ${ }^{5}$, and the issuing of capitularies ${ }^{6}$. And they continue to do so in the most recent work. For instance, in Johannes Fried's biography of Charlemagne published in 2014, the capitulary appears in time-honoured fashion as evidence for Charlemagne's concern for the lower echelons of society under pressure from the demands of their lords, a veritable piece of $»$ social legislation « $(\text { Sozialgesetzgebung })^{7}$. Alongside its presence below the line in monographs and articles, the capitulary has been honoured by publication in full translation in German, French and Italian, and a partial translation in English ${ }^{8}$. These translations reflect a broad consensus in the literature on the precise meaning of the Latin text, though it remains possible to suggest emendations on a couple of points - of which the most important is that the complaint to Charlemagne was not from the peasants, as usually assumed, but was rather about them ${ }^{9}$.

Yet almost as venerable as historians' enthusiasm for this text is a tradition of scepticism about it, reaching back into the nineteenth century with the work of Bernhard von Simson ${ }^{10}$. In more recent years, that scepticism had been set aside thanks to authoritative declarations of the text's authenticity ${ }^{11}$. But in an important article published in 2005, Gerhard Schmitz revived old suspicions, arguing that this much-used text was probably not by Charlemagne at

Große, Ludwig der Fromme und die Freien : Wer waren die liberi homines der karolingischen Kapitularien (742/743-832) ? Ein Beitrag zur Sozialgeschichte und Sozialpolitik des Frankenreichs, Berlin, 1963, p. 111 ; A. Dopsch, Die Wirtschaftsentwicklung der Karolingerzeit, vornehmlich in Deutschland, Weimar, 1921-1922, vol. I, p. 32.

${ }^{5}$ Ch. de Montesquieu, L'esprit des lois, Geneva, 1748. I owe this reference to B. von Simson, « Pseudoisidor und die Le Mans-Hypothese », in Zeitschrift der Savigny-Stiftung für Rechtsgeschichte. Kanonistische Abteilung, 4, 1914, p. 1-73, though it is actually to be found in ch. 5, not 6, of Montesquieu's book 13. More recently on the same topic, L. Feller, Paysans et seigneurs au Moyen Age, VIII ${ }^{e}-X V^{e}$ siècles, Paris, 2007, p. 17. ${ }^{6}$ C. Pössel, « Authors and Recipients of Carolingian Capitularies », in R. Corradini, R. Meens, C. Pössel, and P. Shaw (ed.), Texts and Identities in the Early Middle Ages, Vienna, 2006 (Forschungen zur Geschichte des Mittelalters, 13), p. 253-276, esp. p. 258, with n. 37.

${ }^{7}$ J. Fried, Karl der Große. Gewalt und Glaube : eine Biographie, Munich, 2013, p. 228-229, follows here the line already developed by K. von Inama-Sternegg, Deutsche Wirtschaftsgeschichte, vol. I, Leipzig, 1879, noting at p. 376 the capitulary of Le Mans as part of Charlemagne's efforts for the « Bewahrung eines kräftigen Bauernstandes ».

${ }^{8}$ Translations: J.-P. Devroey, Puissants et misérables. Système sociale et monde paysan dans l'Europe des Francs (VI ${ }^{e}-X^{e}$ siècles), Brussels, 2006, p. 539-540 ; A. Verhulst, The Carolingian Economy, Cambridge, 2002, p. 48 ; L. Kuchenbuch, Grundherrschaft im früheren Mittelalter, Idstein, 1991 (Historisches Seminar, 1), p. 109-110 ; B. Andreolli and M. Montanari, L'azienda curtense in Italia. Proprietà della terra e lavoro contadino nei secoli VIII-XI, Bologna, 1983, p. 65-66.

${ }^{9}$ I have made a new English translation available online: http://www.history.dept.shef.ac.uk/translations/medieval/le-mans-capitulary/. All previous translators have assumed that the complaint was from the peasants, not about them, but C. Wickham, Framing the Early Middle Ages. Europe and the Mediterranean, Oxford, 2005, p. 290, in my view rightly emphasises the role of the landholders in the capitulary. In fact the key phrase in the text, reclamatio de, in capitularies usually means « a complaint about », not «a complaint from ». See also below, n. 31 on the meaning of adiurnare.

${ }^{10}$ See B. von Simson, Die Entstehung der pseudo-isidorischen Fälschungen in Le Mans, Leipzig, 1886, p. 124127 ; consolidated in his Jahrbücher des fränkischen Reiches unter Karl dem Großen, vol. II, Leipzig, 18831888, p. 217 (esp. n. 1) ; further developed in his 1914 article «Pseudoisidor und die Le Mans-Hypothese », as n. 5.

${ }^{11}$ For instance, F.-L. Ganshof, Recherches sur les capitulaires, Paris, 1958, p. 200, n. 242. 
all, but instead was one of a number of forgeries invented by Benedict Levita, the author (or team of authors) responsible for a gigantic and decidedly jumbled collection of legal texts put together in middle ninth-century Francia, many of which are patently not what they claim ${ }^{12}$. Schmitz softened the impact of his bombshell by suggesting that the capitulary was not intrinsically very important anyway : after all, we already know that Frankish peasants owed labour services, so the text was $»$ not particularly striking $\ll^{13}$.

In this chapter, I want to revisit both the status and significance of the Capitulary of Le Mans. I shall argue that its links to Charlemagne are indeed fairly tenuous, as Schmitz pointed out, but that there is good reason to believe that Benedict Levita might not have made it up entirely. Above all, though, I want to suggest that arguments about authenticity have distracted from a full appreciation of its significance, which has been underappreciated in spite of its low-profile ubiquity. It is not simply a text that conveniently illustrates wellknown conditions, ideal for citation in footnotes or for translation for students. Rather, no matter who composed it, the Capitulary of Le Mans is valuable for what it tells about the horizons of expectation of Carolingian kingship at a certain moment ; moreover, if properly contextualised, it can tell us something about some of the dynamics of change of that kingship too.

\section{I.}

Widespread acceptance in the scholarly literature notwithstanding, the notion that Charlemagne issued the Capitulary of Le Mans in the year 800 rests upon evidence that is, as both von Simson and Schmitz observed, flimsy. To begin with, the capitulary's attribution to the year 800 is the product of pure speculation on the part of earlier editors ${ }^{14}$. The text itself is undated in all manuscripts. It is true that in the year 800, Charlemagne travelled through western Francia en route to Tours ; but there is no evidence that he took a detour to Le Mans at this time (or indeed at all), let alone issued a capitulary there ${ }^{15}$.

\footnotetext{
${ }^{12}$ G. Schmitz, «Echtes und Falsches. Karl der Große, Ludwig der Fromme und Benedictus Levita », in O. Münsch (ed.), Scientia Veritatis. Festschrift für Hubert Mordek zum 65. Geburtstag, Ostfildern, 2004, p. 154172.

${ }^{13}$ Ibid., «nicht besonders auffällig ». On importance of labour services in the early medieval world, see Feller, Paysans, as n. 5, p. 62-63 ; on three-day service, Devroey, Puissants et misérables, as n. 8, p. 523.

14 J. Sirmond, Concilia antiqua Galliae, Paris, 1629, p. 243, was perhaps the first to suggest the date of 800 .

15 The only evidence that Charlemagne ever went to Le Mans is provided by the deeply suspect account of Actus pontificum Cenomannis in urbe degentium, ed. M. Weidemann, vol. I, Mainz, 2002 (Römisch-Germanisches Zentralmuseum. Monographien, 56), p. 95, 100. Florian Mazel is preparing a new edition and translation of this text.
} 
Doubts are not however confined to the matter of the capitulary's precise date : they touch too on the more fundamental matter of whether Charlemagne was responsible for this text in any way whatsoever. True, it is included in the capitulary collection of Benedict Levita (Book I, ch. 303), and Benedict's preface claimed that all his texts were issued by Pippin,

Charlemagne or Louis the Pious. Knowingly or not, though, Benedict was often wrong about this. A great many texts in his collection were demonstrably not issued by these or indeed any other Frankish rulers, so the capitulary's presence there is not in itself compelling evidence in favour of an attribution to Charlemagne ${ }^{16}$.

Ostensibly more promising is the capitulary's preservation outside Benedict Levita's collection in two closely-related manuscripts, Vatican, Reg. lat. 69 and Paris, BnF, ms. lat. 5577, complete with a rubric attributing it to »Lord Charles«(Domnus Karolus). These twin manuscripts, both copies of a collection of Alcuin's letters with various additions, used to be thought ninth- or tenth-century on palaeographical grounds, an early dating which supported assumptions about the capitulary's association with Charlemagne. However, Jean Vezin argued in the 1970s that the script of these manuscripts is »archaizing «, and that they are really from the tenth or even the eleventh century ; since then, historians and palaeographers alike have generally (though not universally) followed his redating ${ }^{17}$. As a consequence, it now seems sure that Benedict Levita manuscripts are the earliest witnesses to the capitulary. In his 2005 article, Schmitz further suggested that textual variants ruled out the possibility that Benedict had copied whatever the Vatican and Paris manuscripts were based on, and proposed that they might on the contrary actually be excerpts from Benedict Levita.

Given Benedict's reputation as a forger, such a finding does not inspire confidence, yet it does not in itself prove that the text is an outright forgery. Schmitz however further suggested that the capitulary's rubric ascribing it to Charles was in itself an indication of falsification, on the grounds that attribution to a named king was something consistently associated in Benedict's collection with texts of dubious authenticity ${ }^{18}$. And it is certainly the case that, viewed with a sceptical eye, some of the capitulary's details jar with an attribution to Charlemagne. For instance, the capitulary makes reference to a count of the palace Adelard,

\footnotetext{
${ }^{16}$ On whether Benedict Levita's prologue was a later addition, see below n. 37.

${ }^{17}$ For instance, D. A. Bullough, Alcuin. Achievement and Reputation : Being Part of the Ford Lectures Delivered in Oxford in Hilary Term 1980, Leiden and Boston, 2004 (Education and Society in the Middle Ages and Renaissance, 16), p. 36, n. 78, p. 67-68, n. 163. Ninth- or tenth-century dates are however maintained for the Paris manuscript by D. Howlett, «Fredegisus, De substantia nihili et tenebrarum », in Archivum Latinitatis Medii Aevi, 64, 2006, p. 123 ; and for the Vatican manuscript by S. Keefe, Water and the Word. Baptism and the Education of the Clergy in the Carolingian Empire, vol. II, Notre Dame, 2002, p. 104-105 (with detailed description), though she may have simply relied here on Wilmart's catalogue.

${ }^{18}$ Schmitz, «Echtes und Falsches », as n. 12.
} 
who is otherwise unattested in Charlemagne's reign. Moreover, the capitulary presupposes a heavily manorialised rural settlement, with dependants obliged to carry out a great deal of corvée labour. Such organisation was never widespread in Maine, and it would be remarkable for it to be attested there as early as 800 . Perhaps for that reason, the text is relatively seldom cited in specialist research on the region's agricultural structures ${ }^{19}$.

It is clear then that the capitulary cannot be attributed to Charlemagne without hesitation. Nevertheless it seems scarcely more likely that Benedict Levita made up his text from whole cloth. To begin with, the text is at first sight somewhat peripheral to Benedict's main interests, which tend to focus on elites, not on peasant dues. That there might have been some authentic kernel is further suggested by the capitulary's use of the term factus, a label for a unit of land that is almost exclusively found in mid-ninth-century texts from western Francia, and specifically from the area around Le Mans and to its south ${ }^{20}$. Such is the term's regional specificity that Frankish authors who used it, like the compiler of the polyptych of the monastery of St-Maur-des-Fossés, felt compelled to explain that factus was a synonym for the much more common word mansus, exactly as did Benedict ${ }^{21}$. It is difficult to imagine why a forger would have used a vocabulary so specific that it needed glossing.

Other peculiarities of the text are not quite as decisive as they might seem in casting suspicion on the capitulary. Its documentary or Urkundennähe format might seem strange - a kind of blend between capitulary and diploma - and it may be that Benedict sometimes transformed royal charters into capitularies ${ }^{22}$. Yet the genre of capitularies was a flexible one, and capitularies with a certain Urkundencharakter, or documentary flavour, are far from

\footnotetext{
${ }^{19}$ For a study of regional differences in manorial organisation within Francia with attention to Maine, see M. Rouche, «Géographie rurale du royaume de Charles le Chauve », in M. Gibson and J. Nelson, with D. Ganz, (ed.), Charles the Bald. Court and Kingdom, Oxford, 1981, p. 193-211; and R. Latouche, Origines de l'économie occidentale, Paris, 1956. Corroboratory written evidence is provided by a fragment of a contemporary polyptych from the region which conspicuously makes no reference to labour service : Actus, ed. Weidemann, as n. 15, vol. I, p. 171-172. There has been little settlement archaeology in this region, but for what there is, see J.-Ph. Bouvet (ed.), La Sarthe, Paris, 2001 (Carte archéologique de la Gaule, 72), and J. Naveau (ed.), La Mayenne, Paris, 1992 (Carte archéologique de la Gaule, 53). Cf. D. Pichot, Le village éclaté. Habitat et société dans les campagnes de l'ouest au Moyen Âge, Rennes, 2002 and R. Barton, Lordship in the County of Maine, c. 890-1160, Woodbridge, 2004, neither of whom make use of the capitulary.

${ }^{20} \mathrm{H}$. Miyamatsu, «Factos id est mansos. Régime agraire de l'Ouest de la France à l'époque franque », in C. Laurent, B. Merdrignac and D. Pichot (ed.), Mondes de l'Ouest et villes du monde. Regards sur les sociétés médiévales. Mélanges en l'honneur d'André Chédeville, Rennes, 1998, p. 437-444.

${ }^{21}$ For instance, D. Hägermann and A. Hedwig, Das Polyptychon und die Notitia de areis von Saint-Maur-desFossés. Analyse und Edition, Sigmaringen, 1990 (Beihefte der Francia, 23), p. 93 : factos, id est mansos.

${ }^{22}$ E. g. Benedict Levita, Capitularia, ed. Pertz, MGH Leges, vol. II/2, Hanover, 1837, I, 272, p. 61 ; cf. also II, 370, 371 and 407, p. 91-92, 96. These texts are most easily now accessed through the online edition by G. Schmitz currently in progress : http://www.benedictus.mgh.de/ (14/08/2016).
} 
unusual $^{23}$. And while attribution to a named king is often found in texts of dubious authenticity in Benedict's collection, that is not in fact universally the case ${ }^{24}$.

If it therefore seems unlikely that Benedict invented the text, it is also by no means clear that the Vatican and Paris manuscripts were extracts from Benedict, and not traces of an independent transmission, irrespective of their palaeographical dating. Excerpts from Benedict Levita were certainly common, but they are usually either more substantial, or are clearly marked as $\operatorname{such}^{25}$. It is admittedly unusual to see the word capitulum as a rubric in manuscripts for stand-alone capitularies, as it is in both the Paris and Vatican manuscripts, yet it is nevertheless sometimes to be found elsewhere alongside the more common capitulare and capitula, and capitularies were often designated in this way by other texts (not least in other capitularies $)^{26}$. Finally, the major textual variant to which Schmitz drew attention in his article - the corruption of manuale to annuale, making manual work into annual work - in fact only occurs in the Paris manuscript, not in the Vatican one, so it may be an error introduced in the copying process, not present in whatever was copied. There is nothing else to suggest that the text in these manuscripts depended on Benedict's collection, as distinct from representing an independent line of transmission.

If the text might not have been issued by Charlemagne, but was presumably not entirely invented by Benedict either, then we ought to entertain other possibilities. One I would like to raise is that the Domnus Karolus in question could have been not Charlemagne, but a young Charles the Bald ${ }^{27}$. Whereas no Adelard is known from the court of Charlemagne, there was someone of that name who was very prominent at Charles's court. He is admittedly not

\footnotetext{
${ }^{23}$ The term is from R. Schneider, «Zur rechtliche Bedeutung der Kapitularientexte », in Deutsches Archiv, 23, 1967, p. 273-294, at p. 283. More broadly on the flexibility of the « genre », see R. Schneider,

«Schriftlichkeit und Mündlichkeit im Bereich der Kapitularien », in P. Classen (ed.), Recht und Schrift im Mittelalter, Sigmaringen, 1977 (Vorträge und Forschungen, 23), p. 257-279. For more recent assessments, see $\mathrm{Ph}$. Depreux, «Les préceptes pour les Hispani de Charlemagne, Louis le Pieux et Charles le Chauve », in P. Sénac (ed.), Aquitaine et Espagne (VIII ${ }^{\text {au XIII }}$ siècle), Poitiers, 2001 (Civilisation médiévale, 12) p. 19-38, on the so-called capitularies for the Hispani ; S. MacLean, «Legislation and Politics in Late Carolingian Italy. The Ravenna Constitutions », in Early Medieval Europe, 18, 2010, p. 394-416; and S. Patzold, « Normen im Buch. Überlegungen zu Geltungsansprüchen so genannter "Kapitularien" », in Frühmittelalterliche Studien, 41, 2007, p. 331-350.

${ }^{24}$ Schmitz, as n. 12.

${ }^{25}$ On excerpts, see E. Seckel, «Benedictus Levita decurtatus et excerptus. Eine Studie zu den Handschriften der falschen Kapitularien », in Festschrift für Heinrich Brunner zum fünfzigjährigen Doktorjubiläum am 8. April 1914, überreicht von der Juristenfakultät der Universität Berlin, Berlin, 1914, p. 377-464.

${ }^{26}$ For its appearance as a rubric, see $\mathrm{H}$. Mordek, Bibliotheca capitularium regum Francorum manuscripta. Überlieferung und Traditionszusammenhang der fränkischen Herrschererlasse, Munich, 1995 (MGH. Hilfsmittel, 15), p. 49, 434, 798, 850. For references in other texts, see A. Bühler, «Capitularia relecta. Studien zur Entstehung und Überlieferung der Kapitularien Karls des Großen und Ludwigs des Frommen », in Archiv für Diplomatik, 32, 1986, p. 305-502, particularly p. 322-326. As an example, see MGH. Capit., vol. II, ed. A. Boretius and V. Krause, Hanover, 1890-1897, no. 273, p. 319 : quia super illam legem vel contra ipsam legem nec antecessores nostri quodcumque capitulum statuerunt nec nos aliquid constituimus (Edict of Pîtres, ch. 20). ${ }^{27}$ A possibility already hinted at von Simson, Jahrbücher, as n. 10, vol. II, p. 217, n. 1.
} 
known to have acted as a count of the palace for Charles, but then our lists of counts of the palace are plainly incomplete : we know of only five from Charles the Bald's long reign, even though more than one was sometimes active at the same time. Some of these figures are attested by just a single charter, and there are known gaps in the evidence, such as the absence of any judgement diplomata issued by Charles before $860^{28}$. What is more, Adelard was certainly active in the west of Charles's kingdom in that period ${ }^{29}$. And while Charlemagne hardly ever went to the area of Le Mans, preferring to spend his time in the east, Charles the Bald by contrast visited the area frequently, particularly during the early part of his reign ${ }^{30}$. For example, we know that Charles was at Le Mans in early 841 ; in November 843 he was at Coulaines, just outside the city; he visited again in 845 .

A date early in Charles the Bald's reign would better suit the slow spread of manorial structures in western Francia, of which this text seems to indicate the very moment of imposition $^{31}$. It would make a better context too for certain elements of the vocabulary, the team-work element of the arrangement, and indeed the stress on the written form ${ }^{32}$. It would also, as we shall see, fit well with some of Charlemagne's grandson's other activities ${ }^{33}$. We

\footnotetext{
${ }^{28}$ For absence of judgement diplomata, see Recueil des actes de Charles II le Chauve, roi de France (840-877), ed. G. Tessier et al., 3 vol., Paris, 1943-1955, vol. III, p. 31, 195-197. For a list of counts of the palace, see J. Nelson, Charles, London, 1992, p. 265-266. For two counts of the palace working at the same time, see Recueil, ed. Tessier, vol. II, nos. 258 and 259, p. 81-89. Adelard, incidentally, is not named as Charles the Bald's seneschal either : Nelson, Charles the Bald, p. 266. In general, see Ph. Depreux, « Le rôle du comte du Palais à la lumière des sources relatives au règne de l'empereur Louis le Pieux », in Frühmittelalterliche Studien, 34, 2000, p. 94-111.

${ }^{29}$ On Adelard, see Nelson, Charles, as n. 28, and Ph. Depreux, Prosopographie de l'entourage de Louis le Piéux (781-840), Sigmaringen, 1997, p. 80, both drawing on foundational work by Ferdinand Lot. Adalard seems to have been the titular abbot of St Martin of Tours in $843:$ Recueil, ed. Tessier, as n. 28, vol. I, no. 20, p. 46-49.

${ }^{30}$ See A. Krah, Die Entstehung der potestas regia im Westfrankenreich während der ersten Regierungsjahre Kaiser Karls II. (840-877), Berlin, 2000, p. 61-64 (describing Le Mans as a centre for Charles's Königsherrschaft in 841), p. 97, 118, 208.

${ }^{31}$ This text is the only known Carolingian appearance of the Latin word adiurnare : see J. Niermeyer and C. Kieft, Mediae Latinitatis lexicon minus, Darmstadt, 2002, p. 25, and Mittellateinisches Wörterbuch bis zum ausgehenden 13. Jahrhundert, Munich, 1959, p. 198. All translations of the text (see above, n. 8), apart from Verhulst whose translation is partial, interpret non adiurnati as «not yet summoned $»(e . g$. ., « die nicht (vor)geladen waren », « la cui causa non era all'ordine del giorno »). However, D. Hägermann, «Wandel in Technik und Gesellschaft. Neuansatz und Verlust, Angleichung und Transformation im Übergang von der Spätantike zum frühen Mittelalter », in C. Giefers, D. Hägermann, W. Haubrichs and J. Jarnut (ed.),

Akkulturation : Probleme einer germanisch-romanischen Kultursynthese in Spätantike und frühem Mittelalter, Berlin, 2004, p. 491-503, supposes that it might instead mean they had not been previously subjected to « day service » : « noch nicht zum Tagesdienst eingeteilt », p. 494, which seems very plausible.

${ }^{32}$ The vocabulary of reclamatio has a later feel : other than this text, it appears only in capitularies from 826 , 844 and 864 (cf. Benedict Levita, ed. Pertz, as n. 22, I, 36, p. 48). Moreover, the «team-work » of the labour service perhaps echoes the method of military recruitment introduced under Charlemagne in 807 : Capit., vol. I, ed. Boretius, as n. 2, no. 48, p. 134. For further discussion of this method of recruitment, see T. Reuter, «The End of Carolingian Military Expansion », in P. Godman and R. Collins (ed.), Charlemagne's Heir, Oxford, 1990, p. 391-405, n. 22. For the stress on the written form, see Schneider, «Zur rechtliche Bedeutung der Kapitularientexte », as n. 23.

${ }^{33}$ See below, p.
} 
might further note that the lost Vorlage of the Paris and Vatican manuscripts, as already mentioned essentially a collection of Alcuin letters, had apparently received some mid-ninth century additions relating to Charles the Bald, as recently shown by Brigitte Kasten ${ }^{34}$. If Benedict, perhaps working in Neustria in the 840s, found a text labelled as a »capitulary of Lord Charles « in the context of a set of material connected to Alcuin, just as it is in the Vatican and Paris manuscripts, it would hardly be surprising if he (or they) assumed that it was by Charlemagne, and so added it into the capitulary collection in good faith ${ }^{35}$.

It is of course the case that no capitulary issued by Charles the Bald survives from before 843 (Coulaines), but that is hardly evidence that he did not produce any, given the familiar problems of textual transmission from the early Middle Ages ${ }^{36}$. The window of time in which Charles could have produced such a capitulary stretches from 837, when he took over his regnum, to Adelard's move east in 844, so the transfer into Benedict Levita's collection would have had to be quick, given the conventional dating of this compilation to c. $847^{37}$. Yet our capitulary might not be the only instance of texts from Charles the Bald's early reign sneaking into Benedict Levita ${ }^{38}$.

\section{II.}

It should be clear by now that the question of whether Benedict Levita invented this text, or whether it really was issued by a king (whether Charlemagne or Charles the Bald), or perhaps some combination of the two, is difficult to determine definitively. Such uncertainty is hardly unusual for capitularies, and indeed debates over authorship and authenticity - arguably attempts to force these texts into modern frameworks - are potentially a distraction from more important issues, much as were older discussions about whether capitularies were « essentially » oral or written. The Capitulary of Le Mans is a case in point. In light of the

\footnotetext{
${ }^{34}$ B. Kasten, «Alkuins erbrechtliche Expertise für Karl den Großen ? », in Annales de Bretagne, 111, 2004, 301-318.

${ }^{35}$ Benedict Levita certainly connected Alcuin and Charlemagne : Tertio siquidem in libello post eiusdem libelli capitulorum numerum quaedam ex canonibus a Paulino episcopo, et Albino magistro, reliquisque iussione Karoli inuictissimi principis magistris sparsim collecta sunt inserta capitula (Benedict Levita, ed. Pertz, as $\mathrm{n}$. 22, p. 40). Confusion between different kings called Charles and Louis was a common occurrence in the early Middle Ages, leading many cartulary scribes astray ; chroniclers explicitly commented on the difficulty, $e . g$. Richer of Reims, Historiae, ed. H. Hoffmann, Hannover, 2000 (MGH Scriptores, 38), p. 35.

${ }^{36}$ See $\mathrm{n} .28$ above on the strange lack of any judgement charters from the early part of Charles the Bald's reign. ${ }^{37}$ That dating depends on the preface, but Eric Knibbs in currently unpublished work has cast doubt on whether the preface was a core part of Benedict Levita's collection, in which case elements of the collection could actually be older than generally supposed. Nevertheless the text as it survives today, including the preface and the Capitulary of Le Mans, certainly post-dates 847.

${ }^{38}$ E. Seckel, «Studien zu Benedictus Levita VI », in Neues Archiv, 31, 1906, p. 59-139, on Benedict Levita I, 375 : « aus einem verlorenen Capitulare Ludwigs d. Fr. oder eines seiner Söhne ?? [sic] », p. 124.
} 
importance of Benedict Levita's capitulary collection in late ninth-century Francia - plenty of early manuscripts, and even occasional citation by kings in later capitularies - even if neither Charlemagne nor Charles the Bald had issued the capitulary, they might as well have done so by the time Benedict's work was finished ${ }^{39}$. We might therefore decide that narrow questions of authorship are not the only ones that matter, and turn instead to the text itself.

By and large, however, recent historians have not found the capitulary's content particularly interesting. It is certainly frequently cited, as already mentioned, but usually only as a vivid example of the commonplace. Up to a point, this is perfectly understandable. We do not need to read the Capitulary of Le Mans to know that kings controlled landed estates, and occasionally put orders about them into writing. Nor do we need to read the capitulary to learn that labour service was widespread in the Carolingian countryside (though of course to varying degrees). Nor, finally, do we depend on this particular capitulary to understand that there was on occasion peasant resistance to these demands, in whose resolution kings were involved. All these points are perfectly well demonstrated by other sources.

Nevertheless, in several important regards our capitulary is more unusual, or even, to borrow von Simson's wording, a « unicum $»^{40}$. To begin with, it bears emphasis that it should not be considered as one of the many disputes about peasant status. The capitulary only talks of homines ecclesiastici, fiscalini, and familia. None of these terms applies primarily or exclusively to the unfree : they are in effect functional, not status, classifications ${ }^{41}$. Given the importance of ploughing in the text as the benchmark for service, and the association of ploughing with freedom in early medieval society, many of these people may well have been legally free, but their legal status was not the issue ${ }^{42}$. Though these men were not labelled rustici, or peasants, they may as well have been : all that mattered, and all that was contested, was their service. This instantly sets the capitulary apart from most early medieval peasant disputes, which tend to mediate questions of obligation through arguments about legal status :

\footnotetext{
${ }^{39}$ For a positive evaluation of Benedict's role in the Francia of Charles the Bald, see R. McKitterick, « History, Law and Communication with the Past in the Carolingian Period », in Comunicare e significare nell'alto medioevo, Spoleto, 2005 (Settimane di studio del Centro italiano di studi sull'alto medioevo, 52), p. 941-981, particularly p. 969-978.

${ }^{40}$ Von Simson, «Pseudo-Isidor », as n. 5, Appendix, p. 69, emphasising that this is the only « gesetzliche Regelung dieser Frondienste ».

${ }^{41}$ E. g. Ut homines fiscalini sive coloni vel servi, in Capit., vol. I, ed. Boretius, as n. 2, no. 56, p. 143.

${ }^{42}$ On the association between freedom and ploughing, see J.-P. Devroey and A. Jaubert, « Family, Income and Labour », in E. Vanhaute, I. Devos and T. Lambrecht (ed.), Making a Living : Family, Income and Labour, Turnhout, 2012, p. 5-46, and Kuchenbuch, «Bene laborare », as n. 3.
} 
the nearest parallel is, perhaps significantly, a dispute concerning dependants of the monastery of Cormery, also in western Francia ${ }^{43}$.

Secondly, it is striking that « King Charles » simply sweeps aside custom, usually so important in relations between landlords and tenants. This king does not claim to be reestablishing or upholding older conditions : his decision about the level of obligations is explicitly based not on the past, but on what seemed sensible, on reflection and after consultation $^{44}$. This is not at all the same as ordering that inventories of royal estates be made, or that royal estate managers should carry out their duties conscientiously, as demanded by the Capitulary de Villis ${ }^{45}$. Rather, in this text the king decides on a basic question of estate management himself. Von Simson pointed out that this was quite simply unparalleled, and that whenever historians talk about kings' direct involvement in manorial affairs, it was to this text they turned. That is I think still the case ${ }^{46}$. The detail of labour service was not something that kings usually dealt with ; it was not, in other words, something that usually fell within the remit of « kingship».

For von Simson, preoccupied with the question of false or true, this feature of the text was primarily significant as an indication of its inauthenticity, which he wanted to prove in pursuit of his larger (and now discredited) argument that the whole set of Pseudo-Isidorian forgeries had been made at Le Mans. What strikes the modern historian who looks beyond the specific, perhaps unanswerable and possibly even inappropriate question of capitulary « authorship » in this instance is something different. No matter who the author, for a ninthcentury text to show kings setting out the working week of dependants in this way marks a substantial expansion in the «horizon of expectations » of kingship, the unprecedented enactment of royal commands in a new social field ${ }^{47}$.

\footnotetext{
${ }^{43}$ C. Wickham, «Space and Society in Early Medieval Peasant Conflicts », in Uomo e spazio nell'alto Medioevo, Spoleto, 2003 (Settimane di studio del Centro italiano di studi sull'alto medioevo, 50), p. 551-587 ; on Cormery, see J. Nelson, «Dispute settlement in Carolingian West Francia », in W. Davies and P. Fouracre (ed.), The Settlement of Disputes in Early Medieval Europe, Cambridge, 1986, p. 45-64.

${ }^{44}$ On custom, see above all H.-W. Goetz, «Herrschaft und Recht in der frühmittelalterlichen Grundherrschaft », in Historisches Jahrbuch, 104, 1984, p. 392-410.

${ }^{45}$ Cf. Capitulare de villis ; as D. Campbell, « The Capitulare de Villis, the Brevium Exempla and the Carolingian Court at Aachen », in Early Medieval Europe, 18, 2010, p. 243-264, points out, most attention is given to what ends up at the palace.

${ }^{46}$ Cf C. Wickham, Framing, as n. 9, p. 290 : «I have always found it hard to imagine kings specialising in this level of micro-managerial interest. » The only apparent exception he cites is, unsurprisingly, the Capitulary of Le Mans. Cf. also E. Magnou-Nortier, Aux origines de la fiscalité moderne. Le système fiscal et sa gestion dans le royaume des Francs à l'épreuve des sources, $V^{e}-X I^{e}$ siècles, Geneva, 2012, p. 571, as evidence for « définitions publiques ».

${ }^{47}$ Cf M. Costambeys, M. Innes and S. MacLean, The Carolingian World, Cambridge, 2011, for discussion of legislation as chiefly ideological in function, p. 225. I borrow the phrase « horizon of expectations », stressing interaction between subject and ruler, from I. Garipzanov, The Symbolic Language of Authority in the Carolingian World (c.751-877), Leiden, 2008, p. 24-25.
} 
Unprecedented, indeed : yet that does not mean that the intervention depicted in the Capitulary of Le Mans is entirely without a context altogether. It is in fact in seeking to place this text within such a context that we can best grasp its value for the historian. To begin with, it is worth noting that King Charles the Bald (rather more so than Charlemagne) was demonstrably concerned with peasant dues and obligations, albeit articulated through disputes over legal status, as in the celebrated dispute over Mitry in the 860s. Indeed Charles even issued (other ?) capitularies that dealt with similar questions : most famously the Edict of Pîtres, whose section on requiring peasants to cart marl also edged its way around manorial custom, though less breezily than the Le Mans text ${ }^{48}$.

Perhaps stronger parallels though are with two well-known clauses in the Lex Alamannorum and Lex Baiuvariorum, two related law codes that circulated widely in the Frankish world (Benedict Levita himself drew on the Bavarian law code in his collection) ${ }^{49}$. In the Alaman law code, title 21 refers to the obligations of servi ecclesiae to work three days a week ${ }^{50}$. Chapter 13 of the first title of the Bavarian law code similarly refers to servi ecclesiae, again working for three days a week ${ }^{51}$. Here too, then, we would seem to have evidence for generalised regulation of the obligations of those at the lower end (if not necessarily at the very bottom) of the social hierarchy ${ }^{52}$. The thematic connection between these texts and the Capitulary of Le Mans has often been noted before ${ }^{53}$. Viewed in this light,

\footnotetext{
${ }^{48}$ For Mitry, see J. Nelson, « Dispute settlement », as n. 43. For the Edict of Pîtres's requirement for marling, Capit., vol. II, ed. Boretius and Krause, as n. 26, no. 273, ch. 29, p. 323.

${ }^{49}$ On Benedict Levita's use of the Lex Baiuvariorum, see G. Schmitz, « Benedictus Levita und die Lex Baiuvariorum. Eine quellenkritische Studie », in Zeitschrift der Savigny-Stiftung. Kanonistische Abteilung, 128, 2011, p. 20-58. On the circulation of the text as a whole, see R. Kottje, «Lex Baiuvariorum : das Recht der Baiern », in H. Mordek (ed.), Überlieferung und Geltung normativer Texte des frühen und hohen Mittelalters, Sigmaringen, 1986, p. 9-23 (and n. 67 below on the existence of an extract).

${ }^{50}$ Lex Alamannorum, ed. K. A. Eckhardt, Hanover, 1966 (MGH. Leges nat. Germ, 5/1), p. 82-83 : Servi enim ecclesiae tributa sua legitime reddant : quindecim siclas de cervisa (...). Ancillae autem opera inposita sine neglecto faciant. Servi dimidium sibi et dimidium in dominico arativum reddant; et si super haec est, sicut servi ecclesiastici ita faciant tres dies sibi et tres in dominico.

${ }^{51}$ Lex Baiuvariorum, ed. E. von Schwind, Hanover, 1926 (MGH. Leges nat. Germ, 5/2), p. 289: Servi autem ecclesiae secundum possessionem suam reddant tributa. Opera vero III dies in ebdomada in dominico operet, III vero sibi faciat. Si vero dominus eius dederit eis boves aut alias res, quas habet, tantum serviat, quantum ei per possibilitatem inpositum fuerit. Tamen iniuste neminem opprimas.

52 Devroey, Puissants et misérables, as n. 8, p. 55, talks of the clauses as expressing « le désir d'organiser d'une manière nouvelle et d'unifier les rapports de production et les charges paysannes au sein des domaines royaux et ecclésiastiques ».

${ }^{53}$ E. g. by Devroey, Puissants et misérables, as n. 8, p. 535-542 ; von Simson, « Pseudo-Isidore », as n. 5 ; cf. also W. Goffart, «From Roman Taxation to Mediaeval Seigneurie : Three Notes », in Speculum, 47, 1972, p.
} 
the Capitulum looks like little more than the restatement of generic tradition in a specific setting.

The matter is however both more complicated and even more interesting than it might at first seem. The date of the law codes in question has long been controversial, and remains so to this day ${ }^{54}$. Some historians have argued that both are essentially eighth-century texts, whether from the early part of that century (Alamannian) or from the middle (Bavarian). Others, though, emphasising resonances with Late Antique legislation, have suggested it is possible to discern fossilised traces of seventh-century, or even earlier, legislative activity in both $\operatorname{codes}^{55}$. For most historians, their position on the dating of the law codes in general has determined their understanding of these clauses in particular. Hägermann, for instance, who assumed the Bavarian law code was from the 740s, accordingly saw the clause of I 13 as evidence for the early eighth century ${ }^{56}$. In contrast, Goffart, who viewed these leges as essentially traces of Late Antique vulgar Roman law, interpreted them as showing that Merovingian kings had « issued one or more laws prescribing the services of royal and ecclesiastical peasants in elaborate and circumstantial detail », and suggested that these in turn might have been based on now lost Roman precedents ${ }^{57}$.

The controversy over the dating of the leges as a whole is unlikely to find a resolution any time soon. In fact, it is possible to defend an ultra-late dating of both codes in their current form to the early reign of Charlemagne, if we set aside inconclusive references to « Bavarian law » in charters and other texts and concentrate on the surviving manuscripts, none of which

165-187, 373-394, here at p. 390, n. 200, juxtaposing the capitulary with the leges clauses ; and Inama-Sternegg, Deutsche Wirtschaftsgeschichte, as n. 7 above, p. 376.

${ }^{54} \mathrm{~A}$ useful online resource on Carolingian law codes is being put together by a team at Cologne : see http://www.leges.uni-koeln.de/ (14/08/2016). On the Lex Baiuvariorum, see P. Landau, Die Lex Baiuvariorum. Entstehungszeit, Entstehungsort und Charakter von Bayerns ältester Rechts- und Geschichtsquelle, Munich, 2004. On the Lex Alamannorum, see C. Schott, «Lex und Skriptorium. Eine Studie zu den süddeutschen Stammesrechten », in G. Dilcher (ed.), Leges - Gentes - Regna. Zur Rolle von germanischen Rechtsgewohnheiten und lateinischer Schriftkultur, Berlin, 2006, p. 257-290, who controversially describes it as « eine im Kloster Reichenau entstandene Fälschung » and W. Hartmann, « Einige Fragen zur Lex Alamannorum », in H. Nuber, H. Steuer and T. Zotz (ed.), Der Südwesten im 8. Jahrhundert aus historischer und archäologischer Sicht, Stuttgart, 2004, p. 313-333.

${ }^{55}$ For a recent forceful intervention in favour of an early kernel, see S. Esders, « Spätrömisches Militärrecht in der Lex Baiuvariorum », in F. Botta and L. Loschiavo (ed.), Civitas, iura, arma. Organizzazioni militari, istituzioni giuridiche e strutture sociali alle origini dell'Europa (sec. III-VIII), Lecce, 2015, p. 43-78. Cf. J. Couser, "Let them make him Duke to rule that people" : the Law of the Bavarians and Regime Change », in Law and History Review, 30, 2012, p. 865-899.

${ }^{56}$ D. Hägermann, « Einige Aspekte der Grundherrschaft in den fränkischen formula und in den leges des Frühmittelalters », in A. Verhulst (ed.), Le grand domaine aux époques mérovingienne et carolingienne, Gent, 1985, p. 51-77, here at p. 71-74.

${ }^{57}$ W. Goffart, «Three Notes », as n. 53, here at p. 390, drawing on Heinrich Brunner. 
is earlier than the late eighth century ${ }^{58}$. In any case, whatever the merits of such a position, we need to distinguish arguments about putative textual kernels, impossible to reconstruct with complete certainty, from arguments about the date of the specific clauses in question.

The absence of the Lex Alamannorum clause from the older text known as the Pactus Alamannorum gives at least some reason to imagine that this clause may be eighth-century in date. The clause is also, it must be admitted, rather garbled. It requests church servi to pay a set of dues in kind as «tribute », and ancillae to work « without neglect », then decrees a crop-sharing agreement for servi, before demanding that « if there is anything more » $(s i$ super haec est) they should then perform three days work, confusingly « like church servi» (sicut servi ecclesiastici) ${ }^{59}$. It is difficult to understand precisely what is being established here ; perhaps different texts have been clumsily juxtaposed.

The Lex Baiuvariorum clause is in all likelihood a later text, because it is part of a section (clauses 10-13) probably added to the Bavarian law-code in the late eighth century, perhaps in the $770 \mathrm{~s}^{60}$. Very plausibly it is a response to, and clarification of, the Alamannic text ${ }^{61}$. As already mentioned, it too requests that servi pay tribute and work for three days a week, but adds that if the lord has given him oxen (boves), the servus should do whatever is requested, but without oppression. The contradictions and ambiguities of the Alamannian clause are thereby removed, and the reference to the lord's allocation of livestock perhaps implies a more integrated estate management, as well as implying the performance of ploughing duties, not specified in the Alamannian text.

The development of these two clauses therefore allows us to catch a glimpse of changes in the concept of three-day work as a general burden for servi. But there is a further dimension here, which is the changing status of the law codes themselves in which these clauses were

\footnotetext{
${ }^{58} \mathrm{Cf}$. the classic work by H. Nehlsen, «Zur Aktualität und Effektivität germanischer Rechtsaufzeichnungen », in Classen (ed.), Recht und Schrift, as n. 23, p. 449-502, showing that references to « Salic law » in charters need not be references to the written law as it survives today.

${ }^{59}$ For the Latin, see n. 50 above. The English translation by T. Rivers, Laws of the Alamans and Bavarians, Philadelphia, 1977, p. 73, glosses over these difficulties by ignoring the sicut, thereby removing the strange contrast of servi to church servi.

${ }^{60} \mathrm{~K}$. Beyerle, Lex Baiuvariorum. Lichtdruckwiedergabe der Ingolstädter Handschrift des bayerischen Volksrechts mit Transkription, Textnoten, Übersetzung, Einführung, Literaturübersicht und Glossar, Munich, 1926, p. LXXIX-LXXXI, summarises convincing arguments by Schwind, Merkel and Krusch that I, 13 was part of a later addition to the text, not least because I, 10-13 are all rubricated, and together seem like a set of later additions. This position is accepted by (for example) T. Rivers, "Seigneurial Obligations and "Lex Baiuvariorum" I 13 », in Traditio, 31, 1975, p. 336-342, here at p. 343, and id., "Pre-Carolingian Seigneurial Obligations in Lex Alamannorum XXI-XXII, 1 and their Relationship to the St. Gall Charters (754-770 A. D.) », in Mediaeval Studies, 40, 1978, p. 375-386, at p. 374. Cf. also Devroey, Puissants et misérables, as n. 8, p. 529.

${ }^{61}$ On the Lex Baiuvariorum's use of the Lex Alamannorum, see Hartmann, «Einige Fragen », as n. 54. See however Esders, « Spätrömisches Militärrecht», as n. 55, p. $\underline{58-}$, for a note of caution.
} 
read. These codes were explicitly records of regional custom, but through their prefaces and occasional other references, both had royal associations. These associations however became stronger over the course of the late eighth and ninth centuries, as the two law codes were drawn into what was effectively a new genre, that of «barbarian law codes » (leges barbarorum), collecting together texts of diverse origins into the same manuscripts, and implicitly or otherwise, identifying them with royal Frankish authority ${ }^{62}$. This integration into a royal interpretative framework was moreover not only carried out through the process of manuscript compilation. Charlemagne himself, in fact, made an unmistakable effort to «appropriate » the Bavarian law code, which by that point included this clause, through issuing a capitulary intended to complement it ${ }^{63}$.

With these considerations in mind, the connection between the Capitulum in pago Cenomannico datum and these law-code clauses takes on a slightly different form. What we can see is an evolutionary change in the role played by Carolingian kingship in texts about manorial authority. That evolution began with ambiguous comments about church dependants from the early eighth century in a customary law context ; it was followed by a clarification and development of the notion in the later eighth century, alongside a concomitant stress on the royal authority that increasingly explicitly authorised the norms that the texts proclaimed. In the ninth century, the author (or scribes) of the Capitulary of Le Mans subsequently applied an originally south German concept to western Francia, now leaving no room at all for ambiguity about the role of kings in buttressing manorial authority. It may be significant that the closest parallel in terms of linking dependants both to law codes and to kings comes from the area around Le Mans just a generation later, in a peculiar fragment of the Gesta Aldrici which claimed that royal estates were regulated by either the Lex Salica or the Lex Ribuaria ${ }^{64}$. The implication that peasants, whether free and unfree, were so directly concerned by kingship is unusual in the ninth century, but resonates strongly with the Capitulary of Le Mans.

As such, the Capitulary of Le Mans was not an anodyne restatement of tradition, but attested a trajectory of growing claims about royal power over those working on the land irrespective of their status. In seeking to account for this trajectory, we should remember that older practices of estate management were increasingly coming under pressure from

\footnotetext{
${ }^{62}$ Esders, «Spätrömisches Militärrecht » as n. 55, p. 45, with further references.

${ }^{63}$ T. Faulkner, « Carolingian Kings and the Leges Barbarorum », in Historical Research, 86, 2013, p. 443-464. Faulkner's new book, Law and Authority in the Early Middle Ages : The Frankish Leges in the Carolingian Period, Cambridge, 2016, sheds more light on these matters.

${ }^{64}$ Actus, ed. Weidemann, as n. 15 above, vol. I, p. 156.
} 
intensifying networks of aristocratic control in the ninth-century Frankish countryside, drawing attention to the nature of authority exercised over rural dependants ${ }^{65}$. But we should also remember that Carolingian clerics and intellectuals, advisors to kings and controllers of great quantities of land, undoubtedly found deeply unsettling the idea that something as inchoate as unwritten custom could play so powerful a role in so crucial an area of life as the estate $^{66}$. They made efforts to codify the status quo through polyptychs and other texts, but the lack of any foundational, written basis for specifically manorial authority might well have seemed a problem for educated elites, both clerical and secular, accustomed as they were to making sense of the world through texts.

The clauses in the Alamannian, and still more Bavarian, law codes offered the glimmer of a solution for such a problem. It is therefore intriguing to note that the Bavarian clause circulated in Francia as an independent extract, and did so moreover in a slim legal manuscript (Paris, BnF, ms. lat. 4995) with a clear estate-management context, to judge from a list of dues entered into a spare page ${ }^{67}$. Still, the equivocal status of this law code, and above all its strong regional focus, made this an unsatisfactory resolution. What the Capitulary of Le Mans represents, on this reading, is a more satisfactory answer, by means of unambiguous recourse to kingship in preference to tradition.

In this light, the fact that the Capitulary of Le Mans was included in the collection of Benedict Levita, as almost the sole text there concerning peasants, becomes less perplexing. Wide-ranging to the point of incoherence, the only thing really tying the collection together at all is the insistence that all its texts were royal in origin. Like Ansegis, but even more so, this is a king-centred view of the world, taken to an extravagant, almost parodic extreme ${ }^{68}$. The logic of Benedict's collection therefore matched the logic of the Capitulary of Le Mans itself, as kingship expanded conceptually into new spheres ${ }^{69}$. Far from representing a distortion of the original transmission of the text, far from creating a «problem » with it, the incorporation

\footnotetext{
${ }^{65}$ Wickham, Framing, as n. 9, p. 290.

${ }^{66}$ Cf. Devroey, Puissants et misérables, as n. 8, p. 597, 609.

${ }^{67}$ Paris, BnF, ms. lat. 4995 (s. X), f. 19 for the extract from the Lex Baiuvariorum, and f. 9v for the list of estate dues. See Mordek, Bibliotheca, as n. 26, p. 549-555. Thanks to Tom Faulkner for bringing this interesting manuscript to my attention. Mordek suggested it was largely based on an exemplar put together under the reign of Charlemagne, though he was not sure about the provenance of the Bavarian law clause.

${ }^{68}$ For Ansegis as providing a king-centred view, see S. Airlie, " "For It is Written in the Law". Ansegis and the Writing of Carolingian Royal Authority », in S. Baxter, C. Karkov, J. Nelson and D. Pelteret (ed.), Early Medieval Studies in Memory of Patrick Wormald, Aldershot, 2009, p. 219-236.

${ }^{69}$ On changes in written law, cf. S. Patzold, «Die Veränderung frühmittelalterlichen Rechts im Spiegel der "Leges": Reformen Karls des Großen und Ludwigs des Frommen », in S. Esders and C. Reinle (ed.), Rechtsveränderung im politischen und sozialen Kontext mittelalterlicher Rechtsvielfalt, Münster, 2005, p. 6399.
} 
of this Neustrian text into Benedict Levita's collection represents a perfectly logical development.

$I V$.

According to twelfth-century legend, Charlemagne made a decree about what clothes peasants should wear ${ }^{70}$. It may be that the story that he issued a decree about how much work they should do is hardly better founded. Yet however inappropriate it may be to do so in a volume dedicated to Charlemagne 1,200 years after his death, I suggest that this would not make the Capitulum any less thought-provoking for historians of early medieval Europe, because questions about authorship and authenticity are not the only ones that ought to be asked about capitularies, including - perhaps especially - this one. Whoever the capitulary's author, its representation of kings issuing formal decrees on the labour owed by mere peasants, even those resident on royal land, implies an astonishingly wide-angled view of kingship's responsibilities and powers, a point which has not been fully credited by recent research.

This chapter has suggested that it is possible to make better sense of the decree by setting it in a longer-term trajectory, reaching back at least into the eighth century - a trajectory in which, as we have seen, Charlemagne certainly played a role, albeit not necessarily as author. Still, it remains the case that such an intervention had been neither undertaken by nor attributed to kings in Francia before the capitulary was composed in its current form, probably during the early reign of Charles the Bald, and possibly with that king's involvement. By way of conclusion, however, it is also important to note that such a royal intervention was not undertaken in Francia afterwards, either : at least not until the late tenth and early eleventh centuries, and then in very different terms, when Capetian kings intervened to annul or to regulate consuetudines levied from royal and non-royal lands ${ }^{71}$.

Admittedly, if we compare the Capitulary of Le Mans with the historiographically celebrated «Three Orders » representation of society as organised into those who work, fight and pray, a concept which seems to have emerged in Francia a generation or two after the

\footnotetext{
${ }^{70}$ W. Hartmann, Karl der Große, Stuttgart, 2010, p. 257-258.

${ }^{71}$ For early regulations of « custom » by these kings, see O. Guillot, «Les consuetudines au sens d'exactions dans la France des premiers temps capétiens », in E. Magnou-Nortier (ed.), Pouvoirs et libertés au temps des premiers Capétiens, Maulévrier, 1992, p. 232-246.
} 
capitulary was first copied, the similarities are superficially striking ${ }^{72}$. The « Three Order» classification too reflected a clearer differentiation between increasingly confident elites and increasingly (though never fully) subordinated dependants. It also reflected, perhaps, a more positive evaluation of the labour that those dependants performed, and that came to characterise them and to define their sphere of activity ${ }^{73}$. Above all, it represented an integration of the agricultural masses into a grand, satisfying social schema, theologically grounded and amenable to textual treatment in ways that the enormous diversity of local conditions, considered in all their rich detail, would never permit.

Depicting a body of people, legally undifferentiated and characterised chiefly by their labouring capacity, under the watchful authority of a ruling group, themselves defined by their collective exercise of authority, the Capitulary of Le Mans clearly has much in common with this slightly later representation, first attested from the 860s. Yet the concept of the «Three Orders » tended inherently to play down something upon which the capitulary placed special emphasis : namely, the importance of kingship as a source of authority. So while a (probably) mid ninth-century effort to define a group of people, and by extension society more broadly, by their work or function turned to kingship for legitimation, by the later ninth century that step seemed to some no longer necessary - eloquent testimony to the changes in Frankish society and culture in these decades.

Looked at in this way, the Capitulary of Le Mans fits into a wider history of how social structures were thought about by elites, and represented by medieval writers. It not only shows us the distinctive role that kings in Charlemagne's wake held in the imaginary of the social order, but also provides insight on how that imaginary had gradually developed, before it was overshadowed by, or evolved into, something rather different. For that reason if none other, and even if now less securely tied directly to the towering figure of Charles the Great himself, this is a text that still deserves historians' attention and analysis.

\footnotetext{
72 On the Three Orders, see D. Iogna-Prat, «Le "Baptême" du schéma des trois ordres fonctionnels : l'apport de l'école d'Auxerre dans la seconde moitié du IX ${ }^{\mathrm{e}}$ siècle », in Annales, 41, 1986, p. 43-61, and G. Oexle, «Tria genera hominum. Zur Geschichte eines Deutungsschemas der sozialen Wirklichkeit in Antike und Mittelalter », in L. Fenske, W.Rösener and T. Zotz (ed.), Institutionen, Kultur und Gesellschaft im Mittelalter. Festschrift für Josef Fleckenstein zu seinem 65. Geburtstag, Sigmaringen, 1984, p. 483-500 ; more generally on early medieval social ordering, H.-W. Goetz, «Les ordines dans la théorie médiévale de la société : un système hiérarchique? », in F. Bougard, D. Iogna-Prat and R. Le Jan (ed.), Hiérarchie et stratification sociale dans l'Occident médiéval, Turnhout, 2008, p. 221-236. On Haimo in particular, see E. Ortigues, « L'élaboration de la théorie des trois ordres chez Haymon d'Auxerre », in Francia, 14, 1986, p. 27-44.

${ }^{73}$ J. Nelson, «The Church and a Re-evaluation of Work in the Ninth Century ? », in Studies in Church History, 37, 2002, p. 35-43. On the ambiguity of this representation in a wider setting, see also P. Freedman, Images of the Medieval Peasant, Stanford, 1999, especially p. 20-33.
} 